\title{
EVALUASIAN KOMPARASI DARI EFEK SISTEM KONTROL MANAJEMEN MANUFAKTUR KINERJA SAAT OPERASIONAL DENGAN PROGRAM AUDITAN BERBASIS HISTORICAL COST BERPOSTULAT GOING CONCERN: MODEL PATH ANALITIS
}

\author{
Petrolis Nusa Perdana \\ Fakultas Ekonomi, Universitas Negeri Jakarta \\ petrolis98@unj.ac.id
}

\begin{abstract}
This study uses a linear model of structural relations (LISREL) to investigate the influence of management control system (that is the objectives associated with quality, quality feedback and incentive-compensation) on the suitability of the quality and suistainability influence on the quality of customer satisfaction. Comparison management control on the spot with the results of normative audited based on historical cost with going concern postulated where the results show support for the theoretical framework that links objectives, feedback and incentives for quality conformance which is more optimal than the evaluation of past or simultaneously with current implementation. The results also demonstrate the suitability of which has a significant impact on customer satisfaction and also mediates the relationship between the management control system, audit results and customer satisfaction.
\end{abstract}

Keywords: Management Control Systems, Manufacturing Performance, Program Audit, Historical Cost Basis, Going Concern, Path Analytic Model.

Available at:

http://journal.unj.ac.id/unj/index.php/econosains/article/view/938 


\section{PENDAHULUAN}

Strategi manufaktur dewasa ini melihat kualitas produk sebagai salah satu prioritas utama yang hampir absolut untuk mencapai keunggulan kompetitif yang berkelanjutan (Hill 1997). Disisi proses manufaktur, sistem kontrol juga menyoroti cara di mana unit bisnis menyebarkan sumber daya-sumber dayanya (Hayes dan Beroda, 1984) dan efektif dalam menggunakan kekuatan (Swamidass dan Newell 1987) untuk melengkapi strategi bisnis. Sejumlah penelitian yang ada menyelidiki efek langsung dari manufaktur sistem kontrol, misalnya:
a) Pemberdayaan Karyawan
b) Komitmen Karyawan,
c) Kualitas.

Sementara sistem kontrol dapat memiliki banyak efek langsung pada ukuran kinerja. Efek perkiraan dari sistem kontrol pada variabel dependen dapat bergantung dari variabel-variabel lainnya yang dipengaruhi oleh komponen yang disertakan. Untuk itu, ada kebutuhan untuk mengatasi masalah kesesuaian kualitas dalam mengukur kinerja bisnis.

Namun demikian, dalam pelaksanaan program audit yang dilakukan, auditor juga melihat asersi-asersi dalam manajemen sebagai hal yang dapat menilai kinerja masa lampau dan proyeksi kinerja di masa yang akan datang. Hal ini sesuai dengan salah satu postulat akuntansi yaitu going concerns. Manajemen asersi - asersi tersebut adalah:
a) Occurrence
b) Completeness
c) Valuation
d) Right \& Obligation
e) Disclosure

Penjelasan lainnya adalah, dalam manajemen audit dikatakan bahwa tujuan audit manajemen adalah:

a) Menilai kinerja (performance) manajemen dan fungsi perusahaan.

b) Menilai efisiensi dan keekonomisan sumber daya perusahaan (manusia, mesin, dana, harta lainnya).

c) Menilai efektifitas perusahaan dalam mencapai tujuan (objective) yang telah ditetapkan top management.

d) Memberikan rekomendasi kepada top management untuk memperbaiki kelemahan pengendalian internal, sistem pengendalian manajemen, dan prosedur operasional perusahaan dalam rangka meningkatkan efisiensi, keekonomisan dan efektifitas kegiatan operasi perusahaan

Sehingga dengan demikian bisa dikatakan bahwa pendekatan audit dalam manajemen audit adalah menilai efisiensi,efektifitas dan ke-ekonomisan fungsi perusahaan (penjualan dan pemasaran, produk-si, pergudangan dan distribusi, sumber daya manusia, akuntansi dan keuangan). 

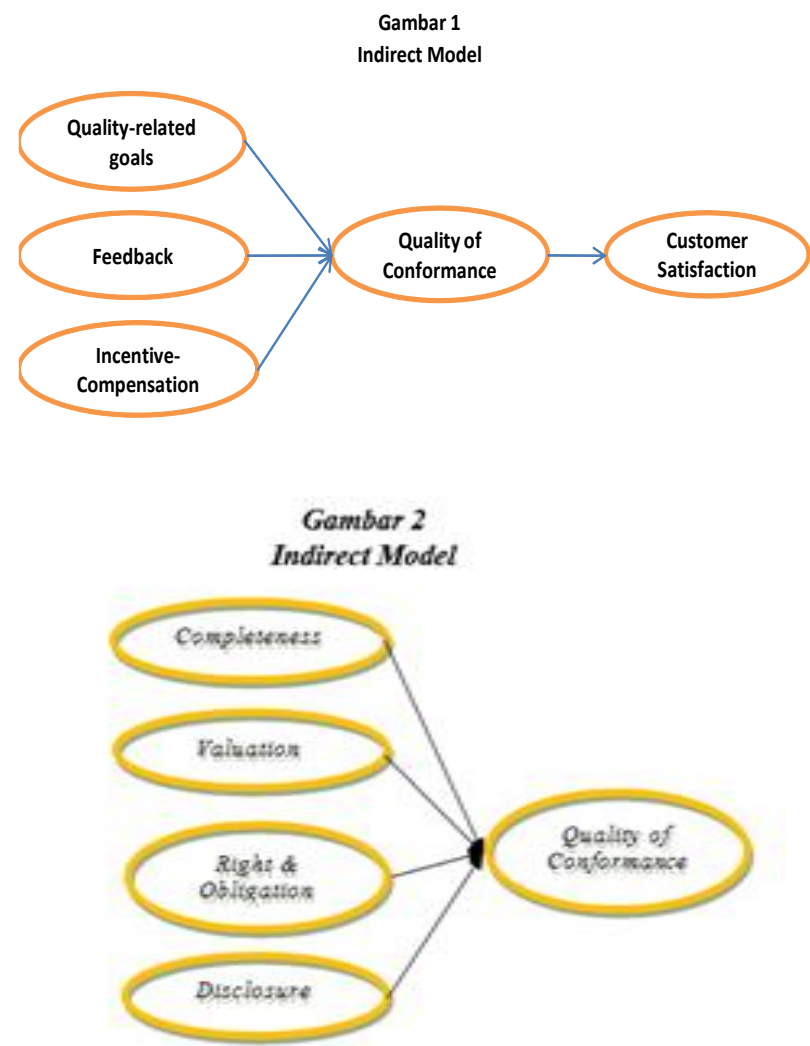

Berdasarkan uraian tersebut, secara lebih spesifik dan lebih rinci, masalah tersebut dapat dipecahkan menjadi sub-sub masalah sebagai berikut:

1. Sejauhmana efek sistem kontrol manajemen manufaktur kinerja saat operasional secara parsial maupun secara simultan berpengaruh dalam Quality of Conforman ceter terhadap Customer Satisfaction.

2. Sejauh mana pengaruh program auditan berbasis historical cost berpostulat going concern secara parsial maupun secara simultan berpengaruh dalam Quality of Conformance terhadap Customer Satisfaction.

\section{KAJIAN PUSTAKA}

Sejumlah penelitian telah menunjukkan bahwa salah satu teknik kontrol manajemen yang paling efektif untuk mencapai peningkatan kinerja adalah untuk memberikan tujuan spesifik, menantang dan umpan balik kepada individu (Locke 1982).

Dari penelitian Wexley dan Yuki (1984) merekomendasikan bahwa karyawan harus memiliki tujuan-tujuan kinerja spesifik untuk panduan perilaku. Oleh karena itu, diharapkan bahwa harmoni antara karyawan dan tujuan organisasi lebih mungkin akan mengakibatkan pencapaian kedua set tujuan bersama. Untuk meneliti hubungan antara tujuan-tujuan yang berhubungan dengan kualitas dan 
kesesuaian kualitas, maka hipotesishipotesis diformulasikan sebagai berikut:

H1: Penggunaan kualitas yang berhubungan dengan tujuan berasosiasi positif dengan kesesuaian kualitas.

Penggunaan nilai informasi kinerja ditentukan diakhir, yang memungkinkan karyawan untuk menentukan cara untuk mereka berpartisipasi. Berbagi informasi kinerja adalah komponen kritis dari proses manajemen (Katz dan Kahn 1978). Jenis-jenis informasi kinerja yang berkumpul dan disebarkan menentukan apakah karyawan pada akhirnya membayar perhatian ke perusahaan (Ilgen et al. 1979). Misalnya, jika informasi kualitas biaya diukur dan disebarkan kepada karyawan, maka karyawan akan membayar lebih banyak perhatian pada kualitas biaya. Kedua, informasi kinerja menyediakan umpan balik kepada karyawan dan manajer mereka dan dengan demikian dapat memberikan petunjuk mengenai daerah-daerah mana untuk perbaikan (Ashford dan Tsui 1991).

H2: Penggunaan umpan balik kualitas yang sering berasosiasi positif dengan kesesuaian kualitas

Penelitian empiris menunjukkan bahwa ketika imbalan terikat untuk kinerja, karyawan akan menyesuaikan upaya mereka untuk mengoptimalkan pendapatan mereka sendiri dan secara bersamaan meningkatkan kinerja organisasi (Cooke 1994; Lawler 1986). Akibatnya, insentif akan meningkatkan kekhawatiran karyawan perusahaan dengan lebih erat mengikat nasib mereka untuk keberhasilan perusahaan (mills dan syahadat 1995). Oleh karena itu, dapat dikatakan bahwa dengan menggunakan insentif kinerja pada kesesuaian kualitas, hipotesisnya dapat diformulasikan:

\section{H3: Penggunaan kompensasi insentif berasosiasi positif dengan kesesuian kualitas}

Gagasan bahwa kinerja pasar dan bisnis secara keseluruhan dapat ditingkatkan melalui peningkatan kualitas produk adalah landasan dari revolusi kontemporer kualitas (George dan Weimerskirch 1994; NIST 1998). Untuk mengeksplorasi hubungan antara kesesuaian kualitas dan kepuasan pelanggan, hipotesis diuji adalah sebagai berikut:

\section{H4: Penggunaan kesesuaian kualitas berasosiasi positif dengan kepuasan pelanggan}

\section{Efek Langsung dari Sistem Kontrol Manajemen pada Kepuasan Pelanggan}

Meskipun dapat dihipotesiskan bahwa kesesuaian kualitas adalah kunci penghubung variabel, tidak berarti bahwa pengaruh langsung kontrol manajemen pada kepuasan pelanggan akan menjadi tidak ada. Sebaliknya, hipotesis untuk peran mediasi kesesuaian kualitas yang 
langsung, dimediasi bebas "setelah" efek (yaitu, setelah akuntansi untuk kesesuaian kualitas) sistem kontrol manajemen pada kepuasan pelanggan akan menjadi kecil (besarnya) dibandingkan dengan efek "sebelum" (yaitu, sebelum mengendalikan mutu kesesuaian (yaitu, kesesuaian kualitas), dan secara tidak langsung dampak kepuasan.

Dengan demikian, hipotesis diusulkan:

H5a: Setelah mengontrol untuk kesesuaian kualitas, efek langsung dan tidak langsung dari kualitas yang berhubungan dengan tujuan pada kepuasan pelanggan akan tidak signifikan.

H5b: Setelah mengendalikan untuk kesesuaian kualitas, efek langsung dan tidak langsung umpan balik kualitas pada kepuasan pelanggan akan tidak signifikan.

H5c: Setelah mengendalikan untuk kesesuaian kualitas, efek langsung dan tidak langsung insentif-kompensasi pada kepuasan pelanggan akan tidak signifikan.

\section{Efek Langsung dari Program Manajemen Audit pada Kepuasan Pelanggan}

Seluruh hipotesis sebelumnya berfokus kepada manajemen pengendalian di saat operasional, sedangkan yang akan di formula- sikan dalam program manajemen audit pada kepuasan pelanggan adalah berdasarkan hasil dan evaluasi serta pengalaman prior year dalam hal kinerja (baik kinerja keuangan dan kinerja-kinerja lainnya, termasuk kinerja performance/ KPI (key performace indicator).

Dengan demikian, hipotesis diusulkan:

H6a: Setelah laporan auditan asersi completeness terpenuhi, efek langsung dan tidak langsung dari kesesuaian kualitas yang berhubungan dengan tujuan pada kepuasan pelanggan akan menjadi tidak signifikan.

H6b: Setelah laporan auditan asersi valuation terpenuhi, efek langsung dan tidak langsung dari kesesuaian kualitas yang berhubungan dengan tujuan pada kepuasan pelanggan akan menjadi tidak signifikan.

H6c: Setelah laporan auditan right \& obligation terpenuhi, efek langsung dan tidak langsung dari kesesuaian kualitas yang berhubungan dengan tujuan pada kepuasan pelanggan akan menjadi tidak signifikan.

H6d: Setelah laporan auditan disclosure terpenuhi, efek langsung dan tidak langsung dari kesesuaian kualitas yang berhubungan dengan tujuan 
pada kepuasan pelanggan akan menjadi tidak signifikan.

\section{METODE PENELITIAN}

Tujuan khusus dari studi ini adalah untuk menyelidiki pengaruh kualitas sistem manajemen kontrol dan pengaruh kesesuaian kualitas pada kepuasan pelanggan. Untuk tujuan ini, selama pertengahan tahun 2016, survei kuesioner digunakan sebagai metode yang efektif untuk mengumpulkan data dari lintas-bagian dari pabrik-pabrik di kawasan industri kabupaten Tangerang.

Sumber utama adalah kawasan industri manufaktur unggulan di kabupaten Tangerang. Sumbersumber tambahan termasuk datadata dari BPS propinsi Banten dan kabupaten Tangerang serta berbagai jurnal berkala tentang teknik industri untukartikel di jurnal apapun yang mungkin menghasilkan laporan kasus atau informasi lainnya untuk menentukan jika TQM diadopsi secara total. Dari sumber di atas, total 39 pabrik secara acak dipilih dan nama-nama manajer pabrik atau manajer kualitas (quality manager) dipilih.

Pertanyaan dalam kuesioner untuk masing-masing variabel, diukur dengan skala Likert.

Tahap-tahap dalam menganalisis data adalah melakukan pengujian kualitas data, setelah memperoleh data dari responden asli lalu membuat tabulasi profil dan jawaban responden, uji asumsi klasik dan menguji hipotesis dengan analisis regresi berganda yang dikomparasi secara kembar. Persamaannya adalah sebagai berikut:

$$
\begin{array}{ll}
a 4 \mathrm{~S} & =\beta 0+\beta 1 \mathrm{P}+\beta 2 \mathrm{U}+\beta 3 \mathrm{~K}+e, \\
\text { lalu: } & \\
\mathrm{Y} & =\beta 0+a 4 \mathrm{~S}+\beta 1 \mathrm{P}+e, \mathrm{dan} \\
\mathrm{Y} & =\beta 0+a 4 \mathrm{~S}+\beta 2 \mathrm{U}+e, \mathrm{dan} \\
\mathrm{Y} & =\beta 0+a 4 \mathrm{~S}+\beta 3 \mathrm{~K}+e, \mathrm{dan} \\
\mathrm{Y} & =\beta 0+a 4 \mathrm{~S}+e
\end{array}
$$

Serta:

$$
\begin{aligned}
& \mathrm{Y}=\beta 0+\beta 1 \mathrm{C}+\beta 2 \mathrm{~V}+\beta 3 \mathrm{R}+\beta 4 D \\
& +a 4 \mathrm{~S}+e \text {, lalu: } \\
& \mathrm{Y}=\beta 0+a 4 \mathrm{~S}+\beta 1 \mathrm{C}+e \text {, dan } \\
& \mathrm{Y}=\beta \mathrm{D}+a 4 \mathrm{~S}+\beta 2 \mathrm{~V}+e, \mathrm{dan} \\
& \mathrm{Y}=\beta 0+a 4 \mathrm{~S}+\beta 3 \mathrm{R}+e, \mathrm{dan} \\
& \mathrm{Y}=\beta \mathrm{O}+a 4 \mathrm{~S}+\beta 4 \mathrm{D}+e, \\
& \text { Keterangan: } \\
& \text { Y: Kepuasan Pelanggan } \\
& \beta 0 \text { : Intersept model } \\
& \text { a: Variabel Penghubung } \\
& \beta 1 \beta 2 \beta 3 \text { : koefisien regresi }
\end{aligned}
$$

$P: \quad$ Penggunaan kualitas yang berhubungan dengan tujuan

U: Umpan balik

K: Kompensasi Insentif

S: Kesesuaian Kualitas

C: Completeness

V: Valuation

R: Right \& Obligation

D: Disclosure

e: error

Toleransi kesalahan (a) yang ditetapkan sebesar 5\% dengan signifikansi sebesar $95 \%$. Penulis menetapkan toleransi kesalahan sebesar $5 \%$, karena nilai tersebut umum digunakan dalam melakukan penelitian.

\section{Pengujian Hipotesis}

Untuk mengetahui pengaruh variable kompetensi, independensi 
dan akuntabilitas terhadap kualitas audit maka dilakukan analisis regresi linier berganda.

\section{Uji Kelayakan Model (Uji F)}

Uji $F$ ini digunakan untuk mengetahui ada tidaknya pengaruh secara bersama-sama (simultan) variabel-variabel independen (bebas) terhadap variabel dependen (terikat). Pembuktian dilakukan dengan cara membandingkan nilai $F$ hitung dengan $\mathrm{F}$ tabel pada tingkat signifikansi $5 \%$ dan derajat kebebasan (degree of freedom) $\mathrm{df}=\mathrm{n}-\mathrm{k}-1$ dimana $\mathrm{n}$ adalah jumlah responden dan $\mathrm{k}$ adalah jumlah variabel. Kriteria pengujian yang digunakan adalah:

Jika $F$ hitung $>F$ tabel (n-k-1), maka $\mathrm{H} 1, \mathrm{H} 2, \mathrm{H} 3, \mathrm{H} 4, \mathrm{H} 5 \mathrm{a}, \mathrm{H} 5 \mathrm{~b}$, $\mathrm{H} 5 \mathrm{c}$, H6a, H6b, H6c, dan H6d diterima, yang memiliki arti secara statistik data yang digunakan membuktikan bahwa semua variabel independen $(\mathrm{H} 1, \mathrm{H} 2, \mathrm{H} 3, \mathrm{H} 4, \mathrm{H} 5 \mathrm{a}$, $\mathrm{H} 5 \mathrm{~b}, \mathrm{H} 5 \mathrm{c}, \mathrm{H} 6 \mathrm{a}, \mathrm{H} 6 \mathrm{~b}, \mathrm{H} 6 \mathrm{c}$, dan H6d) berpengaruh signifikan terhadap nilai variabel dependen $(Y)$.

Jika $F$ hitung $<F$ tabel $(n-k-1)$, maka $\mathrm{H} 1, \mathrm{H} 2, \mathrm{H} 3, \mathrm{H} 4, \mathrm{H} 5 \mathrm{a}, \mathrm{H} 5 \mathrm{~b}$, $\mathrm{H} 5 \mathrm{c}$, H6a, H6b, H6c, dan H6dditolak, yang memiliki arti secara statistik data yang digunakan membuktikan bahwa semua variabel independen $\mathrm{H} 1, \mathrm{H} 2, \mathrm{H} 3, \mathrm{H} 4, \mathrm{H} 5 \mathrm{a}$, $\mathrm{H} 5 \mathrm{~b}, \mathrm{H} 5 \mathrm{c}$, H6a, H6b, H6c, dan H6dtidak berpengaruh signifikan terhadap nilai variabel dependen (Y).

Selain itu, uji $\mathrm{F}$ dapat pula dilihat dari besarnya probabilitas value ( $p$ value) dibandingkan dengan 0,05 (taraf signifikansi $=5 \%$ ). Adapun kriteria pengujian yang digunakan adalah:

Jika $p$ value $<0,05$ maka $\mathrm{H} 1, \mathrm{H} 2$ dan H3 diterima.

Jika $p$ value $>0,05$ maka $\mathrm{H} 1, \mathrm{H} 2$ dan H3 ditolak.

Selanjutnya untuk mengetahui seberapa besar prosentase sumbangan dari variabel independen $\mathrm{H} 1, \mathrm{H} 2, \mathrm{H} 3, \mathrm{H} 4, \mathrm{H} 5 \mathrm{a}, \mathrm{H} 5 \mathrm{~b}, \mathrm{H} 5 \mathrm{c}$, $\mathrm{H} 6 \mathrm{a}$, H6b, H6c, dan H6d secara bersama-sama terhadap kualitas audit sebagai variabel dependen dapat dilihat dari besarnya Koefisien Determinasi (R2), dimana R2 menjelaskan seberapa besar variabel independen yang digunakan dalam penelitian ini mampu menjelaskan variabel dependen.

\section{Uji Parsial (Uji t)}

Untuk memperoleh keyakinan tentang kebaikan dari model regresi dalam memprediksi, harus dilakukan uji signifikansi dari masing-masing koefisien dari model.

Kriteria pengujian yang digunakan adalah:

Jika t hitung $>\mathrm{t}$ tabel $(\mathrm{n}-\mathrm{k}-1)$, maka $\mathrm{H}_{1}, \mathrm{H}_{2}, \mathrm{H}_{3}, \mathrm{H}_{4}, \mathrm{H}_{5 a}, \mathrm{H}_{5 b}, \mathrm{H}_{5 c}$, $\mathrm{H}_{6 \mathrm{a}}, \mathrm{H}_{6 \mathrm{~b}}, \mathrm{H}_{6 \mathrm{c}}$, dan $\mathrm{H}_{6 \mathrm{~d}}$ diterima.

Jika t hitung $<\mathrm{t}$ tabel $(\mathrm{n}-\mathrm{k}-1)$, maka $\mathrm{H}_{1}, \mathrm{H}_{2}, \mathrm{H}_{3}, \mathrm{H}_{4}, \mathrm{H}_{5 \mathrm{a}}, \mathrm{H}_{5 b}, \mathrm{H}_{5 c}$, $\mathrm{H}_{6 \mathrm{a}}, \mathrm{H}_{6 \mathrm{~b}}, \mathrm{H}_{6 \mathrm{c}}$, dan $\mathrm{H}_{6 \mathrm{~d}}$ ditolak.

Selain itu, uji t tersebut dapat pula dilihat dari besarnya probabilitas value ( $p$ value) dibandingkan dengan 0,05 (taraf signifikansi alpha $=5 \%$ ). Adapun kriteria pengujian yang digunakan adalah: 
Jika $\mathrm{p}$ value $<0,05$ maka $\mathrm{H}_{1}$, $\mathrm{H}_{2}, \mathrm{H}_{3}, \mathrm{H}_{4}, \mathrm{H}_{5}, \mathrm{H}_{5 b}, \mathrm{H}_{5 c}, \mathrm{H}_{6 a}, \mathrm{H}_{6 b}$, $\mathrm{H}_{6 c}$, dan $\mathrm{H}_{6 \mathrm{~d}}$ diterima.

Jika $\mathrm{p}$ value $>0,05$ maka $\mathrm{H}_{1}$, $\mathrm{H}_{2}, \mathrm{H}_{3}, \mathrm{H}_{4}, \mathrm{H}_{5}, \mathrm{H}_{5 b}, \mathrm{H}_{5 c}, \mathrm{H}_{6 a}, \mathrm{H}_{6 b}$, $\mathrm{H}_{6 c}$, dan $\mathrm{H}_{6 \mathrm{~d}}$ ditolak.

Untuk mengetahui seberapa besar prosentase sumbangan dari variabel independen $\mathrm{H}_{1}, \mathrm{H}_{2}, \mathrm{H}_{3}, \mathrm{H}_{4}$, $\mathrm{H}_{5 a}, \mathrm{H}_{5 b}, \mathrm{H}_{5 c}, \mathrm{H}_{6 \mathrm{a}}, \mathrm{H}_{6 b}, \mathrm{H}_{6 c}$, dan $\mathrm{H}_{6 \mathrm{~d}} \mathrm{Secara}$ parsial terhadap terhadap kepuasan pelanggan sebagai variabel dependen dapat dilihat dari besarnya koefisien determinasi ( $r 2)$. Dimana r2 menjelaskan seberapa besar variabel independen yang digunakan dalam penelitian ini mampu menjelaskan variabel dependen.

\section{Conformance Quality (Kualitas Yang Memenuhi/Sesuai)}

Kualitas yang memenuhi (sesuai) digunakan sebagai variable anteseden (terdahulu)itudiukur dengan menggunakanempat indikator:
a) Memo
b) mengolah kembali
c) cacat
d) Internal (sebelum pengiriman) ujikinerja produk.

\section{Customer Satisfaction (Kepuas- an Pelanggan)}

Mengikuti penelitian sebelumnya (misalnya Ahiredan Dreyfus, 2000;

\section{Tingkat Penyebaran dan Pengembalian Kuesioner}

Sim dan Killough,1998) kepuasan pelanggan diukur dengan menggunakan empat item;
a) Jumlahprodukklaimgaransi
b) Jumlahlitigasiproduk
c) Jumlahkeluhan pelanggan
d) retur penjualan

\section{hASIL PENELITIAN}

Penelitian ini dilakukan untuk mengetahui apakah variabel-variabel independen yaitu Penggunaan kualitas yang berhubungan dengan tujuan, Umpan balik, Kompensasi Insentif, Kesesuaian Kualitas, Completeness, Valuation, Right \& Obligation, Disclosure dapat mempengaruhi Kepuasan Pelanggan sebagai variable dependen. Objek dalam penelitian ini adalah kawasan industri manufaktur unggulan di kabupaten Tangerang yang terdaftar di dalam direktori industri Dinas Perindustrian dan Perdagangan Kabupaten Tangerang Provinsi Banten. Sedangkan subjek dalam penelitian ini adalah seluruh manajer pabrik atau manajer kualitas (quality manager) dalam direktori industri Dinas Perindustrian dan Perdagangan Kabupaten Tangerang Propinsi Banten tersebut. 
Keterangan

Jumlah

Jumlah Kuesioner yang dikirim 150

Jumlah Kuesioner yang tidak kembali 16

Jumlah Kuesioner yang kembali 134

Jumlah Kuesioner yang tidak dapat digunakan 2

Jumlah Kuesioner yang dapat digunakan 132

Tingkat Pengembalian Kuesioner (Respon Rate) $89,33 \%$

Tingkat Pengembalian Kuesioner yang dapat digunakan (Useable $\quad 98,50 \%$ Rate)

\section{Deskripsi Responden}

Responden dalam penelitian ini adalah para manajer pabrik atau quality manager yang bekerja pada pabrik-pabrik di daerah-daerah yang terbagi dalam beberapa kawasan industri di kabupaten/kotamadya Tangerang dan Tangerang Selatan propinsi Banten Indonesia. Jumlah responden dalam penelitian ini sebanyak 132 orang dengan identitas responden meliputi: jenis kelamin, usia, pendidikan terakhir dan jabatan.

Karakteristik Responden Berdasarkan Jenis Kelamin

\begin{tabular}{clcc}
\hline No. & $\begin{array}{l}\text { Jenis } \\
\text { Kelamin }\end{array}$ & Jumlah & $\%$ \\
\hline 1. & Pria & 113 & $85,61 \%$ \\
\hline 2. & Wanita & 19 & $14,39 \%$ \\
\hline & Total & 132 & $100 \%$ \\
\hline
\end{tabular}

Karakteristik Responden Berdasarkan Usia

\begin{tabular}{cccc}
\hline No. & $\begin{array}{c}\text { Usia } \\
\text { (Tahun) }\end{array}$ & Jumlah & $\%$ \\
\hline 1. & $<30$ & 12 & $9 \%$ \\
\hline
\end{tabular}

\begin{tabular}{cccc}
\hline 2. & $31-40$ & 11 & $8 \%$ \\
\hline 3. & $41-50$ & 79 & $60 \%$ \\
\hline 4. & $>50$ & 30 & $23 \%$ \\
\hline & Total & 132 & $100 \%$
\end{tabular}

Karakteristik Responden Berdasarkan Pendidikan Terakhir

\begin{tabular}{cccc}
\hline No. & $\begin{array}{c}\text { Pendidikan } \\
\text { Terakhir }\end{array}$ & Jumlah & $\%$ \\
\hline 1. & SMA/Diploma & 6 & $5 \%$ \\
\hline 2. & S1 & 123 & $93 \%$ \\
\hline 3. & S2 & 3 & $2 \%$ \\
\hline 4. & S3 & 0 & $0 \%$ \\
\hline & Total & 132 & $100 \%$ \\
\hline
\end{tabular}

Karakteristik Responden Berdasarkan Jabatan

\begin{tabular}{cccc}
\hline No. & Jabatan & Jumlah & $\%$ \\
\hline 1. & Manajer / & 115 & $87 \%$ \\
& quality & & \\
& Controler \\
& Senior & & \\
\hline 2. & Manajer / & 17 & $13 \%$ \\
& quality \\
& Controler \\
& & \\
\hline & & \\
\hline & Totanior & 132 & $100 \%$ \\
\hline
\end{tabular}


Statistik Deskriptif

\begin{tabular}{|l|r|r|r|}
\hline \multicolumn{3}{|c|}{ Descriptive Statistics } \\
\hline Kepuasan Pelanggan (Y) & \multicolumn{1}{|c|}{ Mean } & Std. Deviation & \multicolumn{1}{c|}{$\mathrm{N}$} \\
\hline Penggunaan Kualitas Yang & 41.6212 & 2.59633 & 132 \\
Berhubungan dengan Tujuan (P) & 31.3409 & 2.42074 & 132 \\
\cline { 1 - 1 } Umpan Balik (U) & & & \\
Kompensasi Insentif (K) & 39.9318 & 3.07959 & 132 \\
Kesesuaian Kualitas (S) & 39.9697 & 3.05157 & 132 \\
Completeness (C) & 49.5606 & 3.64714 & 132 \\
Valuation (V) & 41.4242 & 2.64754 & 132 \\
Right \& Obligation (R) & 41.6061 & 2.59406 & 132 \\
Disclosure (D) & 41.5758 & 2.77150 & 132 \\
\end{tabular}

\section{Hasil Uji Statistik Deskriptif}

Tabel di atas menunjukan hasil pengukuran deskriptif terhadap seluruh variabel independen dan variabel dependen dari 132 sampel yang diolah dengan;

a) 3 variabel independen indirect mode/dari kontrol manajemen manufaktur kinerja yaitu:
a. Penggunaan kualitas yang berhubungan dengan tujuan,
b. Umpan balik,
c. Kompensasi insentif

b) 1 variabel penghubung indirect model dari kontrol manajemen manufaktur kinerja dan asersi asersi manajemen audit berbasis historical cost berpostulat going concern yaitu kesesuaian kualitas

c) 4 variabel independen indirect model dari asersi - asersi manajemen audit berbasis historical cost berpostulat going concern yaitu:
a. Completeness
b. Valuation

\section{c. Right \& Obligation \\ d. Disclosure \\ d) Kepuasan Pelanggan adalah variable dependen $(Y)$}

\section{Uji Asumsi Klasik}

Sebelum dianalisis dengan teknik regresi, maka model persamaan regresi harus melalui uji asumsi klasik terlebih dahulu. Model regresi yang baik adalah model regresi yang didalamnya tidak terdapat masalah data yang distribusinya normal, masalah multikolinearitas dan masalah heterokedastisitas.

\section{Uji Normalitas}

$\mathrm{Uji}$ Normalitas bertujuan untuk menguji apakah dalam model regresi, variabel terikat atau variabel bebas keduanya mempunyai distribusi normal ataukah tidak. 


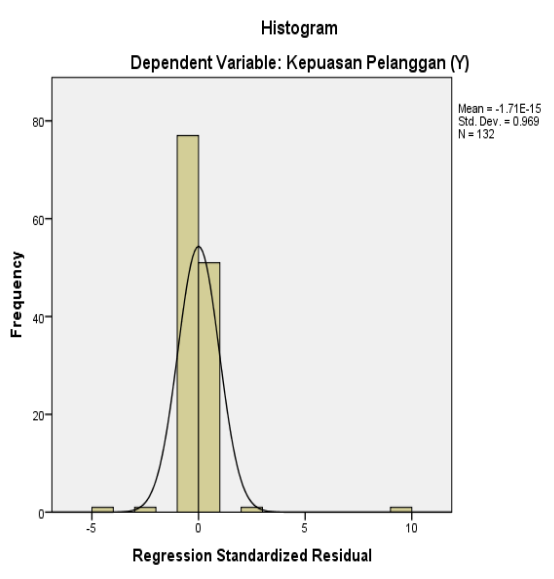

Pada grafik histogram menunjukan pola distribusi normal (tidak memiliki kecenderungan ke kanan atau ke kiri grafik) sehingga dapat disimpulkan bahwa data berdistribusi normal. Grafik tersebut menunjukkan bahwa model regresi memenuhi asumsi normalitas. Untuk memperjelas sebaran dalam penelitian ini maka disajikan grafik normal PPlot.

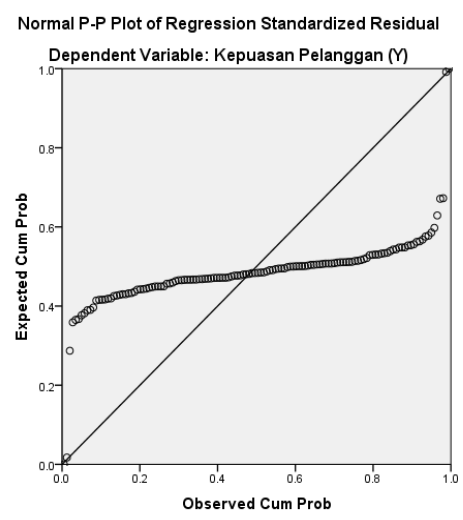

Pada grafik di atas terlihat distribusi titik-titik data menyebar di sekitar garis diagonal dan penyebaran titik-titik searah mengikuti garis diagonal, hal ini mengindikasikan bahwa distribusi data pada penelitian ini normal.

\section{Uji Multikolinearitas}

Setelah melakukan uji normalitas data, dilakukan pula uji multikolinearitas. Uji ini digunakan untuk menguji apakah ditemukan adanya korelasi antara variabelvariabel bebas dalam model regresi. Apabila terjadi gejala multikolinearitas, salah satu langkah untuk memperbaiki. 


\section{Hasil Uji Multikolinearitas (Coefficient Coorrelations)}

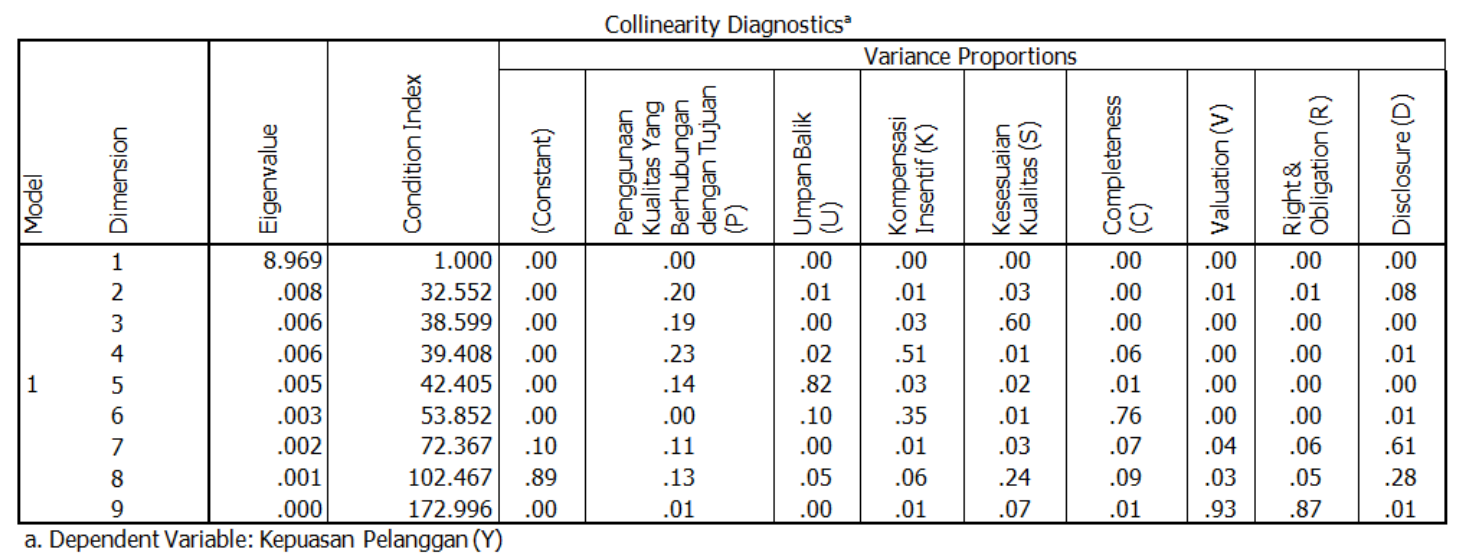

Melihat hasil besaran korelasi antar variabel bebas tampak bahwa hanya variabel valuation yang mempunyai korelasi yang tertinggi di antara variabel lainnya dengan tingkat korelasi zero ordersebesar 0,988 atau sekitar 98,8\%.Oleh karena korelasi ini sudah diatas $90 \%$, maka dapat dikatakan terjadi multikolinearitas. Hasil perhitungan nilai tolerance juga menunjukkan tidak ada variabel bebas yang memiliki nilai tolerance kurang dari $10 \%$ yang berarti tidak ada korelasi antar variabel bebas yang nilainya lebih dari $95 \%$.

\section{Uji Heteroskedastisitas}

Dasar analisis dari penelitian ini adalah jika ada pola tertentu, seperti titik-titik yang ada membentuk pola tertentu yang teratur (bergelombang, melebar kemudian menyempit), maka mengindikasikan telah terjadi heteroskedastisitas. Sedangkan jika tidak ada pola yang jelas, serta titik-titik menyebar di atas dan di bawah angka 0 pada sumbu $Y$, maka tidak terjadi heteroskedastisitas.

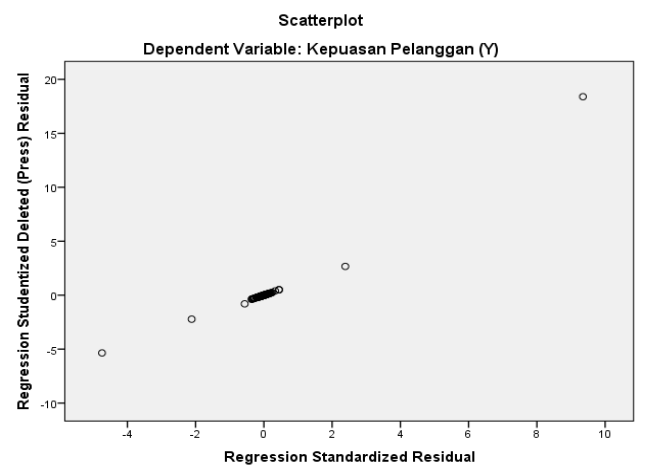

\section{Pengujian Hipotesis}

$\mathrm{Uji}$ regresi linear berganda dilakukan untuk melihat kemampuan variabel independen dalam menjelaskan variabel dependen. Regresi linear berganda menghubungkan satu variabel dependen dengan beberapa variabel independen dalam suatu model prediktif tunggal. $\mathrm{Uji}$ regresi berganda ini dapat dilihat berdasarkan tabel Coefficients. Berdasarkan hasil analisis regresi yang telah dilakukan diperoleh hasil sebagai berikut: 
Coefficients $^{\mathrm{a}}$

\begin{tabular}{|c|c|c|c|c|c|c|c|c|c|c|c|}
\hline & \multirow[t]{2}{*}{ Model } & \multicolumn{2}{|c|}{$\begin{array}{l}\text { Unstandardized } \\
\text { Coefficients }\end{array}$} & \multirow{2}{*}{$\begin{array}{c}\begin{array}{c}\text { Standardized } \\
\text { Coefficients }\end{array} \\
\text { Beta }\end{array}$} & \multirow[t]{2}{*}{$\mathrm{T}$} & \multirow{2}{*}{ Sig. } & \multicolumn{3}{|c|}{ Correlations } & \multicolumn{2}{|c|}{ Collinearity Statistics } \\
\hline & & B & $\begin{array}{l}\text { Std. } \\
\text { Error }\end{array}$ & & & & $\begin{array}{l}\text { Zero- } \\
\text { order }\end{array}$ & Partial & Part & Tolerance & VIF \\
\hline \multirow{9}{*}{1} & (Constant) & .591 & 1.089 & & .543 & .588 & & & & & \\
\hline & $\begin{array}{l}\text { Penggunaan Kualitas } \\
\text { Yang Berhubungan } \\
\text { dengan Tujuan }(P)\end{array}$ & .006 & .015 & .006 & .425 & .672 & .018 & .038 & .006 & .977 & 1.024 \\
\hline & Umpan Balik (U) & -.001 & .013 & -.001 & -.061 & .952 & .213 & -.005 & -.001 & .895 & 1.117 \\
\hline & Kompensasi Insentif $(K)$ & .000 & .013 & .000 & .018 & .985 & .191 & .002 & .000 & .881 & 1.135 \\
\hline & Kesesuaian Kualitas (S) & -.002 & .011 & -.003 & -.209 & .835 & .102 & -.019 & -.003 & .904 & 1.106 \\
\hline & Completeness (C) & -.007 & .015 & -.007 & -.453 & .651 & .232 & -.041 & -.006 & .835 & 1.198 \\
\hline & Valuation(V) & .948 & .039 & .947 & 24.222 & .000 & .988 & .909 & .341 & .129 & 7.743 \\
\hline & Right \& Obligation (R) & .043 & .036 & .046 & 1.199 & .233 & .915 & .107 & .017 & .137 & 7.288 \\
\hline & Disclosure (D) & .000 & .022 & .000 & .016 & .987 & .788 & .001 & .000 & .331 & 3.026 \\
\hline
\end{tabular}

Tabel diatas menunjukan nilai koefisien regresi untuk variabelvariabel independen secara berturut-turut; penggunaan kualitas yang berhubungan dengan tujuan sebesar 0,006; umpan balik sebesar 0,001 ; kompensasi insentif sebesar 0,000; kesesuaian kualitas sebesar 0,002; completeness sebesar 0,007; valuation sebesar 0,948; right \& obligation 0,043; dan disclosure sebesar 0,000. Sehingga persamaan regresinya menjadi:

$$
\begin{aligned}
\mathrm{Y}= & \text { 0,591+0,006P+0,001U+ } \\
& \text { 0,000K+0,002S+0,007C+0,9 } \\
& \text { 48V+0,043R+0,00D+e } \\
& \text { Hipotesis Pertama }\left(\mathrm{H}_{1}\right) .
\end{aligned}
$$

Hipotesis pertama $\left(\mathrm{H}_{1}\right)$ dalam penelitian ini menyatakan $\mathrm{H}_{1}$ ditolak dan $\mathrm{H}_{0}$ diterima. Hal ini berarti tidak ada pengaruh yang signifikan antara variabel penggunaan kualitas yang berhubungan dengan tujuan terhadap variabel kesesuaian kualitas. Jadi, dapat disimpulkan bahwa hipotesis pertama $\left(\mathrm{H}_{1}\right)$ dalam penelitian ini ditolak.

Hipotesis kedua $\left(\mathrm{H}_{2}\right)$ dalam penelitian ini menyatakan bahwa nilai t hitung sebesar $-0,061<\mathrm{t}$ tabel 1,9781 sehingga $t$ hitung $<\mathrm{t}$ tabel, jadi $\mathrm{H}_{2}$ ditolak dan $\mathrm{H}_{0}$ diterima. Hal ini berarti tidak ada pengaruh yang signifikan antara variabel umpan balik terhadap variabel kesesuaian kualitas. Jadi, dapat disimpulkan bahwa hipotesis kedua $\left(\mathrm{H}_{2}\right)$ dalam penelitian ini ditolak.

Hipotesis ketiga $\left(\mathrm{H}_{3}\right)$ dalam penelitian ini menyatakan bahwa nilai t hitung sebesar $0,018<t$ tabel 1,9781 sehingga $\mathrm{t}$ hitung $<\mathrm{t}$ tabel, jadi $\mathrm{H}_{3}$ ditolak dan $\mathrm{H}_{0}$ diterima. Hal ini berarti tidak ada pengaruh yang signifikan antara variabel kompensasi insentif terhadap variabel kesesuaian kualitas. Jadi, dapat disimpulkan bahwa hipotesis kedua $\left(\mathrm{H}_{3}\right)$ dalam penelitian ini ditolak.

Hipotesis Keempat $\left(\mathrm{H}_{4}\right)$ dalam penelitian ini menyatakan bahwa nilai t hitung sebesar 0,209 < t tabel 1,9781 sehingga $t$ hitung $<\mathrm{t}$ tabel, jadi $\mathrm{H}_{4}$ ditolak dan $\mathrm{H}_{0}$ diterima. Hal ini berarti tidak ada pengaruh yang

Available at:

http://journal.unj.ac.id/unj/index.php/econosains/article/view/938 
signifikan antara variabel kesesuaian kualitasterhadap variabel kepuasan pelanggan. Jadi, dapat disimpulkan bahwa hipotesis kedua $\left(\mathrm{H}_{4}\right)$ dalam penelitian ini ditolak.

Hipotesis Kelima $\left(\mathrm{H}_{5 a}\right)$ dalam penelitian ini menyatakan bahwa hasil uji-t yang disajikan pada tabel IV.15 diperoleh nilai $t$ hitung sebesar $0,835<\mathrm{t}$ tabel 1,9781 sehingga $\mathrm{t}$ hitung $<\mathrm{t}$ tabel, jadi $\mathrm{H}_{5 a}$ ditolak dan $\mathrm{H}_{0}$ diterima.

Hipotesis Kelima $\left(\mathrm{H}_{5 b}\right)$ dalam penelitian ini menyatakan bahwa hasil uji-t yang disajikan pada tabel IV.15 diperoleh nilai $t$ hitung sebesar $0,835<\mathrm{t}$ tabel 1,9781 sehingga $\mathrm{t}$ hitung $<\mathrm{t}$ tabel, jadi $\mathrm{H}_{5 b}$ ditolak dan $\mathrm{H}_{0}$ diterima.

Hipotesis Kelima c $\left(\mathrm{H}_{5 c}\right)$ dalam penelitian ini menyatakan bahwa hasil uji-t yang disajikan pada tabel IV.15 diperoleh nilai $t$ hitung sebesar $0,835<\mathrm{t}$ tabel 1,9781 sehingga $\mathrm{t}$ hitung $<\mathrm{t}$ tabel, jadi $\mathrm{H}_{5 c}$ ditolak dan $\mathrm{H}_{0}$ diterima.

Hipotesis Keenam a $\left(\mathrm{H}_{6 a}\right)$ dalam penelitian ini menyatakan bahwa hasil uji-t yang disajikan pada tabel IV.15 diperoleh nilai $t$ hitung sebesar $0,453<\mathrm{t}$ tabel 1,9781 sehingga $\mathrm{t}$ hitung $<\mathrm{t}$ tabel, jadi $\mathrm{H}_{6 a}$ ditolak dan $\mathrm{H}_{0}$ diterima.

Hipotesis Ke enam b $\left(\mathrm{H}_{6 b}\right)$ dalam penelitian ini menyatakan bahwa hasil uji-t yang disajikan pada tabel IV.15 diperoleh nilai $t$ hitung sebesar 24,222> t tabel 1,9781 sehingga $\mathrm{t}$ hitung $>\mathrm{t}$ tabel, jadi $\mathrm{H}_{6 \mathrm{~b}}$ diterima dan $\mathrm{H}_{0}$ ditolak.

Hipotesis Keenamc $\left(\mathrm{H}_{6 c}\right)$ dalam penelitian ini menyatakan bahwa hasil uji-t yang disajikan pada tabel IV.15 diperoleh nilai $t$ hitung sebesar $1,199<\mathrm{t}$ tabel 1,9781 sehingga $\mathrm{t}$ hitung $<\mathrm{t}$ tabel, jadi $\mathrm{H}_{6 c}$ ditolak dan $\mathrm{H}_{0}$ diterima.

Hipotesis Keenam d $\left(\mathrm{H}_{6 \mathrm{~d}}\right)$ dalam penelitian ini menyatakan bahwa 'hasil uji-t yang disajikan pada tabel IV.15 diperoleh nilai $\mathrm{t}$ hitung sebesar $0,016<t$ tabel 1,9781 sehingga $t$ hitung $<t$ tabel, jadi $\mathrm{H}_{6 \mathrm{~d}}$ ditolak dan $\mathrm{H}_{0}$ diterima.

\section{Uji Kelayakan Model (Uji F)}

Hasil uji $F$ dapat dilihat pada output ANOVA dari hasil analisis regresi linier berganda. Dengan menggunakan sampel sebanyak 132 dan tingkat keyakinan 95\%, maka didapat nilai $F$ tabel sebesar 2,68.

$\mathrm{H}_{0}$ : Tidak ada pengaruh yang signifikan antara penggunaan kualitas yang berhubungan dengan tujuan, umpan balik, kompensasi insentif, kesesuaian kualitas, completeness, valuation, right \& obligation dan disclosure terhadap kepuasan pelanggan

$\mathrm{H}_{\mathrm{a}}$ : Terdapat pengaruh yang signifikan antara penggunaan kualitas yang berhubungan dengan tujuan, umpan balik, kompensasi insentif, kesesuaian kualitas, completeness, valuation, right \& obligation dan disclosure terhadap kepuasan pelanggan

Untuk menentukan apakah hipotesis alternatif mengenai pengaruh simultan kedelapan variabel independen terhadap satu variabel 
dependen dalam penelitian ini dapat $\mathrm{F}$ hitung dengan $\mathrm{F}$ tabel.

dilakukan pembandingan nilai antara

Uji Kelayakan Model (Uji-F)

ANOVA $^{\mathrm{a}}$

\begin{tabular}{|c|c|c|c|c|c|}
\hline Model & Sum of Squares & Df & Mean Square & $\mathrm{F}$ & Sig. \\
\hline Regression & 861.596 & 8 & \multirow{3}{*}{$\begin{array}{r}107.699 \\
.175\end{array}$} & \multirow[t]{3}{*}{617.152} & \multirow[t]{3}{*}{$.000^{\mathrm{b}}$} \\
\hline Residual & 21.465 & 123 & & & \\
\hline Total & 883.061 & 131 & & & \\
\hline
\end{tabular}

a. Dependent Variable: Kepuasan Pelanggan $(Y)$

b. Predictors: (Constant), Disclosure (D), Penggunaan Kualitas Yang Berhubungan dengan Tujuan (P), Kesesuaian Kualitas (S), Kompensasi Insentif (K), Umpan Balik (U), Completeness (C), Right \& Obligation (R), Valuation (V)

Berdasarkan tabel di atas, uji pengaruh simultan (Uji-F) sebesar $617,152>2,68$ dan signifikansi sebesar 0,000 dengan demikian $\mathrm{H}_{0}$ ditolak dan $\mathrm{H}_{\mathrm{a}}$ diterima, yang berarti variabel independen yaitu penggunaan kualitas yang berhubungan dengan tujuan, umpan balik, kompensasi insentif, kesesuaian kualitas, completeness, valuation, right \& obligation dan disclosure mempengaruhi variabel dependen yaitu kepuasan pelanggan secara simultan.

\section{Koefisien Determinasi $\left(\mathbf{R}^{\mathbf{2}}\right)$}

\begin{tabular}{|c|c|c|c|c|c|c|c|c|c|c|}
\hline \multicolumn{11}{|c|}{ Model Summary } \\
\hline \multirow[t]{2}{*}{ Model } & \multirow[t]{2}{*}{$\mathrm{R}$} & \multirow[t]{2}{*}{ R Square } & \multirow{2}{*}{$\begin{array}{c}\text { Adjusted R } \\
\text { Square }\end{array}$} & \multirow{2}{*}{$\begin{array}{c}\text { Std. Error of } \\
\text { the } \\
\text { Estimate }\end{array}$} & \multicolumn{5}{|c|}{ Change Statistics } & \multirow{2}{*}{$\begin{array}{l}\text { Durbin- } \\
\text { Watson }\end{array}$} \\
\hline & & & & & $\begin{array}{l}\text { R Square } \\
\text { Change }\end{array}$ & F Change & df1 & $\mathrm{df} 2$ & $\begin{array}{c}\text { Sig. F } \\
\text { Change }\end{array}$ & \\
\hline 1 & $.988^{\mathrm{a}}$ & .976 & .974 & .41774 & .976 & 617.152 & 8 & 123 & .000 & 3.020 \\
\hline
\end{tabular}

Berdasarkan hasil perhitungan di atas, diperoleh nilai Adjusted $R$ Square sebesar 0,974 (97,4\%) yang berarti penggunaan kualitas yang berhubungan dengan tujuan, umpan balik, kompensasi insentif, kesesuaian kualitas, completeness, valuation, right \& obligation dandisclosureberpengaruh terhadap kepuasan pelanggan. Kedelapan variabel independen tersebut mampu menjelaskan variabilitas variabel dependen sebesar 97,4\% sedangkan sisanya yaitu sebesar
2,6\% dijelaskan variabel lain yang tidak dimasukkan ke dalam model regresi.

\section{KESIMPULAN}

Berdasarkan penelitian yang dilakukan, maka dapat disimpulkan hal-hal berikut ini:

1. Tidak terdapat pengaruh yang signifikan kepada kepuasan pelanggan. Hal ini dapat disebabkan karena perbedaan persepsi para manajer pabrik 
atau quality controller factory dalam memberikan pendapat mengenai pengaruh penggunaan kualitas yang berhubungan dengan tujuan terhadap kepuasan pelanggan, mengingat responden yang menjadi subjek penelitian dalam penelitian ini tidak hanya melibatkan manajer senior yang berpengalaman tetapi juga melibatkan manajer junior.

2. Penggunaan umpan balik kualitas yang sering bersosiasi positif dengan kesesuaian kualitas tidak terdapat pengaruh yang signifikan pada kepuasan pelanggan. Hal ini dapat disebabkan karena perbedaan persepsi para manajer pabrik atau quality controller factory dalam memberikan pendapat mengenai umpan balik terhadap kepuasan pelanggan.

3. Penggunaan kompensasi insentif berasosiasi positif dengan kesesuaian kualitas tidak terdapat pengaruh yang signifikan pada kepuasan pelanggan. Hal ini dapat disebabkan karena persepsi para manajer pabrik atau quality controller factory dalam memberikan pendapat mengenai kompensasi insentif tersebut beranggapan bahwa kompensasi insentif merupakan suatu skema dan norma dari mekanisme yang wajar dan sudah seharusnya didapatkan atas kinerja yang mereka lakukan dalam memenuhi target dari produksi yang telah ditetapkan oleh perusahaan.
4. Penggunaan kesesuaian kualitas berasosiasi positif dengan kepuasan pelanggan tidak terdapat pengaruh yang signifikan pada kepuasan pelanggan. $\mathrm{Hal}$ ini dapat disebabkan karena perbedaan persepsi para manajer pabrik atau quality controller factory dalam mem-berikan pendapat mengenai kesesuaian kualitas yang berhubungan dengan tujuan terhadap kepuasan pelanggan. Penyebabnya bisa dikarenakan penggunaan bahan-bahan baku dan mekanisme cara pembuatan dan pemusnahan telah diatur melalui mekanisme atau standar operating procedure (SOP) masing-masing pabrik milik perusahaan dan agar sesuai dengan standar nasional Indonesia (SNI), sehingga mereka tidak memikirkan berbagai inovasi dan kreasi agar pelanggan puas karena mereka hanya mengikuti SOP.

5.a. Setelah mengontrol untuk kesesuaian kualitas, efek langsung dan tidak langsung dari kualitas yang berhubungan dengan tujuan pada kepuasan pelanggan akan tidak signifikan. Hal ini jelas karena pada penggunan kesesuaian kualitas saja, tidak berpengaruh langsung terhadap kepuasan pelanggan, apalagi dengan melalui moderasi gangguan yang harus dikendalikan terlebih dahulu di variabel independen kesesuaian kualitas. 
b. Setelah mengontrol untuk kesesuaian kualitas, efek langsung dan tidak langsung umpan balik pada kepuasan pelanggan akan tidak signifikan. Hal ini jelas karena pada umpan balik saja, tidak berpengaruh langsung terhadap kepuasan pelanggan, apalagi dengan melalui moderasi gangguan yang harus dikendalikan terlebih dahulu di variabel independen kesesuaian kualitas.

c. Setelah mengontrol untuk kesesuaian kualitas, efek langsung dan tidak langsung kompensasi insentif pada kepuasan pelanggan akan tidak signifikan. Hal ini jelas karena pada hubungan langsung kompensasi insentif saja tidak berpengaruh langsung terhadap kepuasan pelanggan, apalagi dengan melalui moderasi gangguan yang harus dikendalikan terlebih dahulu di variabel independen kesesuaian kualitas

6.a. Setelah laporan auditan asersi completeness terpenuhi, efek langsung dan tidak langsung dari kesesuaian kualitas pada kepuasan pelanggan akan tidak signifikan. Memang ada pengaruh bagi para manajer pabrik dan para quality controller dalam hal memenuhi kelengkapan bukti-bukti pekerjaan yang ditargetkan berdasarkan hasil pemeriksaan audit periode sebelumnya, akan tetapi, hal tersebut bukanlah merupakan sesuatu yang signifikan bagi mereka yang disebabkan tingkat kepedulian mereka hanyalah sebtas produksi dan menjga standar kualitas yang telah ditetapkan.

b. Setelah laporan auditan asersi valuation terpenuhi, efek langsung dan tidak langsung dari kesesuaian kualitas pada kepuasan pelanggan akan tidak signifikan. Variabel valuation merupakan variabel yang mempengaruhi secara langsung variabel kepuasan pelanggan secara signifikan. Bagi para manajer pabrik dan quality controller, penilaian dalam konteks harga, baik dalam target beban biaya produksi dan realisasi biaya produksi menurut persepsi mereka akan membuat pelanggan puas.

b. Setelah laporan auditan asersi right \& obligation terpenuhi, efek langsung dan tidak langsung dari kesesuaian kualitas pada kepuasan pelanggan akan tidak signifikan. Hal ini jelas karena pada hubungan langsung antara asersi right \& obligation saja dengan kepuasan pelanggan, tidak memiliki dan tidak berpengaruh langsung terhadap kepuasan pelanggan, apalagi dengan melalui moderasi gangguan yang harus dikendalikan terlebih 
dahulu di variabel independen.

c. Setelah laporan auditan asersi disclosure terpenuhi, efek langsung dan tidak langsung dari kesesuaian kualitas pada kepuasan pelanggan akan tidak signifikan. Pada variabel disclosure atau pengungkapan terhadap catatan catatan atas laporan keuangan (CALK) laporan audit periode sebelumnya, para manajer pabrik atau quality controller mendapatkan laporan audit tersebut. Namun mereka hanya terfokus kepada laporan dan realisasi atas Cost of Good Manufactured (COGM), atau paling jauh hanya terfokus kepada cost of Good Sold (COGS) saja. Sehingga secara keseluruhan, evaluasi atas kinerja mereka menjadi parsial dan statis karena hanya sebatas target jumlah kuantitas produksi dan deviasi nilai produksi riil terhadap nilai produksi yang telah ditargetkan dimuka.

\section{DAFTAR PUSTAKA}

Anthony A. Atkinson, Rajiv D. Banker, Robert S. Kaplan, dan S. Mark Young, 1997. Management Accounting. Edisi ke-2, New Jersey: Prentice Hall,Inc.

Becker, Koen De dan Yamano, Norihiko, 2007. The Measurement of Globalisation Using International Input Output Tables. STI Working Paper No. DST/DOC (2007)8. OECD Directorate of Science, Technology, and Industry Hausmann, Ricardo dan Bailey Klinger, 2006. Structural Transformation and Patterns of Comparative Advantage in the Product Space. Faculty Research Working Papers Series 06-041. Harvard University

Mulyadi \& J. Setyawan, 1999. Sistem Perencanaan dan Pengendalian Manajemen: Sistem Pelipatgandaan Kinerja Perusahaan, Aditya Media, Yogyakarta.

Richard L. Lynch dan Kelvin f. Cross, 1993. Performance Measurement System, Handbook of Cost Management. Peny. Bary Brinker. New York: Warren Gorham Lamont, E3, hal. 328. 